\title{
ACE-inhibitors but not endothelin receptor blockers prevent podocyte loss in early diabetic nephropathy
}

\author{
M.-L. Gross ${ }^{1}$, A. El-Shakmak ${ }^{3}$, A. Szábó ${ }^{3}$, A. Koch ${ }^{1}$, A. Kuhlmann ${ }^{2}$, K. Münter ${ }^{4}$, E. Ritz ${ }^{5}$, K. Amann ${ }^{2}$ \\ ${ }^{1}$ Department of Pathology, University of Heidelberg, Heidelberg, Germany \\ 2 Department of Pathology, University Erlangen, Germany \\ ${ }^{3}$ Department of Pediatric Nephrology, Semmelweis University Budapest, Hungary \\ ${ }^{4}$ Bayer AG, Wuppertal, Germany \\ ${ }^{5}$ Department of Internal Medicine, University of Heidelberg, Germany
}

\section{Abstract}

Aims/hypothesis. It was the aim of our study to investigate the influence of a selective ET-A receptor antagonist LU 135252 alone and in combination with the ACE-inhibitor, trandolapril on podocyte number and morphology in streptozotocin diabetic rats.

Methods. Male Sprague-Dawley rats were injected with $65 \mathrm{mg}$ streptozotocin i.v. and subsequently developed diabetes. Animals were left untreated or received daily either trandolapril $(0.3 \mathrm{mg} / \mathrm{kg}$ body weight $), \mathrm{LU}$ $135252(50 \mathrm{mg} / \mathrm{kg}$ body weight $)$ or a combination of both. After 6 months the experiment was terminated. Glomerular geometry and cellularity were assessed by stereological techniques. Protein expression of TGF$\beta$, ET-1, PDGF-AB, fibronectin, desmin and $\alpha$-smooth muscle cell actin was investigated by immunohistochemistry.

Results. The mean number of podocytes per glomerulus was lower $(86 \pm 17$ vs. $138 \pm 25 ; p<0.05)$ and mean podocyte volume was higher in untreated diabetic animals than in non-diabetic controls. Only ACE-i alone and in combination, but not $\mathrm{ET}_{\mathrm{A}}-\mathrm{RB}$ alone prevented loss of podocytes and podocyte hypertrophy. In diabetic rats, increased numbers of PCNA positive and p27 kip 1 positive cells (mainly podocytes) were reduced by all treatments, but only ACE-i decreased numbers of desmin positive podocytes and tubulointerstitial expression of TGF- $\beta$. Albuminuria was increased in untreated diabetes and was prevented only by ACE-i and combination treatment.

Conclusion/interpretation. Podocyte hypertrophy and degeneration is an early event in diabetic nephropathy leading to a loss of podocytes. Treatment with an ACE-i, but not with an $\mathrm{ET}_{\mathrm{A}}-\mathrm{RB}$, prevented the development of albuminuria as well as damage and loss of podocytes. The well known anti-proteinuric effect of ACE- $\mathrm{i}$ is presumably due at least in part to conservation of podocyte structure. Increased plasma endothelin-1 (ET-1) concentrations and urine excretion of ET-1 have been documented in patients with diabetes and proteinuria [1]. It has been shown that experimental diabetes mellitus increases renal ET-1 gene transcription [2]. To assess the relevance of the ET-system in the pathogenesis of renal structural changes in the model of the STZ-induced diabetic rat we compared the effect of an $\mathrm{ET}_{\mathrm{A}}$-receptor specific antagonist with the well known beneficial effect of an ACE-i, especially on podocyte cell number and morphology. [Diabetologia (2003) 46:856-868]

Keywords Podocyte damage, diabetic nephropathy, endothelin receptor blocker, ACE-inhibitor.
Received: 11 October 2002 / Revised: 17 February 2003 Published online: 11 June 2003

CC Springer-Verlag 2003

Corresponding author: Dr. M.-L. Gross, Department of Pathology, University of Heidelberg, Im Neuenheimer Feld, 69120 Heidelberg, Germany

E-mail: Marie-Luise_Gross@med.uni-heidelberg.de
Abbreviations: ACE-i, ACE inhibitor; $\mathrm{ET}_{\mathrm{A}}-\mathrm{RB}$, endothelin-A receptor blocker; ET-1, endothelin-1; Tr, trandolapril; STZ, streptozotocin; TGF- $\beta$, transforming growth factor- $\beta$; PDGF, platelet derived growth factor; CDK, cyclin dependent kinase; bw, body weight; bp, blood pressure; PCNA, proliferating cell nuclear antigen; GBM, glomerular basement membrane. 
The characteristic progressive increase in urinary protein excretion in diabetic nephropathy points to an important role of podocytes in the pathogenesis of diabetic renal diseases. During embryogenesis primordial and immature podocytes freely enter the cell cycle. Mature podocytes then exit cell cycle and have a differentiated phenotype [3]. At this point they are thought to be incapable of replication. Recent reports suggest that podocyte loss is an important factor for the progression of diabetic glomerulosclerosis [4] and that podocyte damage can be prevented by ACE-i [5]. Cell proliferation is strictly controlled at several points of the cell cycle [6], but the role of specific cell cycle proteins in glomerular hypertrophy of diabetic animals has remained unclear. Cyclin dependent kinase (CDK) inhibitors cause cell cycle arrest by inactivating specific CDK complexes required for cell cycle progression. In the current study we focused on p27 KIP1, the major CDK inhibitor causing cell cycle arrest [7] and used desmin staining as one of the earliest signs of non-specific podocyte damage [8].

The antihypertensive and antiproteinuric effect of ACE-i, as well as their protective effect on glomerular morphology, is well established, but very little is known concerning their action on podocytes in diabetic animals. ET-1 has also been claimed to be involved in diabetic nephropathy but its effect on glomerular morphology is unknown [9].

\section{Material and methods}

Animals. Male Sprague-Dawley rats (Charles River, Germany, mean body weight: $176 \pm 19.8 \mathrm{~g}$ ) were housed at constant room temperature $\left(21^{\circ} \mathrm{C}\right)$ and humidity $(75 \%)$ under a controlled light to dark cycle. The animals had free access to water and standard rat pellets (Altromin 1324, Lage/Lippe, Germany). Experimental diabetes was induced by i.v. injection of $65 \mathrm{mg}$ Streptozotocin (STZ) (Sigma Aldrich, Deisenhofen, Germany). All injected animals developed hyperglycaemia on day 2 after STZ administration. Thereafter, diabetic animals were treated daily with $4.1 \pm 1.4 \mathrm{IU} / \mathrm{kg}$ body weight (bw) of long-acting human insulin (Insulin Ultratard HM, Aventis, Frankfurt/Main, Germany, $40 \mathrm{I} \cdot \mathrm{U} / \mathrm{ml})$. All experiments were conducted in accordance with the "Principles of laboratory animal care".

Experimental protocol. Four days after induction of diabetes the animals were randomly allocated to the following five experimental groups: (i) untreated non-diabetic control animals $(n=8)$; (ii) untreated diabetic animals $(n=10)$; (iii) diabetic animals + $\mathrm{ET}_{\mathrm{A}}$-RB (LU 135252:50 mg/kg bw, $n=9$ ); (iv) diabetic animals + ACE-i (Trandolapril: $0.3 \mathrm{mg} / \mathrm{kg}$ bw, $n=12$ ); (v) diabetic animals $+\mathrm{ET}_{\mathrm{A}}-\mathrm{RB}+\mathrm{ACE}-\mathrm{i}$ (combi: doses as above, $n=12$ ).

Medications were administered in the drinking fluid at concentrations calculated to deliver the above mentioned doses. Daily food and water consumption were monitored and the doses adjusted. Body weight, blood glucose and blood pressure (by tail plethysmography) were measured at regular intervals. After 3, 5 and 6 months, animals were kept in metabolic cages for 24 -h urine collection. Urinary albumin excretion was measured using a rat specific sandwich ELISA system as described in detail elsewhere [10].
After 6 months the experiment was terminated by retrograde aortic perfusion with glutaraldehyde for morphometric and stereological investigations or with ice cold $0.9 \% \mathrm{NaCl}$ for immunohistochemistry and in situ hybridisation, respectively [10]. Perfusion pressure was carefully monitored and adequacy of fixation was examined in pilot experiments. The observation period of 6 months was selected because at this time point various studies had shown marked differences in renal structure between STZ-induced diabetic rats and controls by light microscopy $[11,12,13]$.

Tissue preparation. The kidneys were taken out, weighed and dissected along a plane perpendicular to the interpolar axis, yielding slices of $1 \mathrm{~mm}$ thickness. Ten small pieces of one kidney were selected by area weighted sampling for embedding in Epon-Araldite. Semithin $(1 \mu \mathrm{m})$ and ultrathin sections $(0.08 \mu \mathrm{m})$ were prepared and stained with methylene blue/basic fuchsin or lead citrate/uranyl acetate, respectively. The remaining tissue slices were embedded in paraffin; $4 \mu \mathrm{m}$ sections were prepared and stained with haematoxylin/eosin and Periodic Acid Schiff (PAS). For immunohistological investigations one half of the kidney was fixed in $4 \%$ buffered formaldehyde, embedded in paraffin and cut into $2 \mu \mathrm{m}$ thick sections. For in situ hybridisation, the remaining part of the kidney was snap frozen in liquid nitrogen-cooled isopentane. Paraffin sections were prepared and were incubated with the following antibodies using the avidin biotin method: PCNA (proliferating cell nuclear antigen; $\alpha$-PCNA monoclonal mouse, Immunotech, Marseille, France), P27KIP1 ( $\alpha-\mathrm{P} 27$ polyclonal rabbit, Santa Cruz, Calif., USA), TGF- $\beta_{1}$ (anti-TGF- $\beta_{1}$, rabbit polyclonal IgG, Santa Cruz Biotechnology, Santa Cruz, Calif., USA), $\alpha-$ smooth muscle cell actin (monoclonal mouse, Dako, Glostrup, Denmark) and desmin ( $\alpha$-desmin monoclonal mouse, Capinteria, Calif., USA). Cryostat sections that were $5 \mu \mathrm{m}$ thick were prepared and the sections were incubated with the following antibodies using the avidin biotin method [10]: fibronectin $(\alpha$-fibronectin polyclonal rabbit, Sigma-Aldrich, Steinheim, Germany), endothelin ( $\alpha$-ET-1 polyclonal rabbit, Biotrend, Cologne, Germany) and PDGF-AB (platelet derived growth factor; $\alpha$-PDGF-AB polyclonal goat, Upstate Biotechnology, Waltham, USA). Optimal staining concentration was evaluated testing different dilution series. The following dilutions of antibodies were used: PCNA 1:150 [8], p27KIP1 1:500 [7], desmin $1: 50$ [14], $\alpha$-smooth muscle actin 1:200, TGF- $\beta$ 1:300 [15], ET-1 1:25 [16], fibronectin 1:150 [15] and PDGF 1:50 [15].

To avoid non-specific cross reactions of tissue components with antibody, a biotin-streptavidin detection system (biotinstreptavidin super sensitive; BioGenex, San Ramon, Calif., USA) was selected [10]. Negative controls were carried out by omitting the primary antibody.

Morphological investigations-indices of renal damage (glomerulosclerosis, tubulointerstitial and vascular damage). The degree of sclerosis within the glomerular tuft as an index of progression was evaluated on Periodic Acid Schiff (PAS) stained paraffin sections, adopting the semiquantitative scoring system [17]. All investigations were carried out twice in a blinded manner, that is, the two observers were unaware of the animals study group. The glomerular score of each animal was derived as the mean of 100 glomeruli using light microscopy at a magnification of $\times 400$. The severity of glomerulosclerosis was expressed on an arbitrary scale from 0 to 4 [17]. The glomerular score for individual glomeruli was: grade 0 , normal glomerulus; grade 1, incipient mesangial expansion/thickening of the basement membrane [18], irregular lumina of capillaries; grade 2, mild/moderate segmental hyalinosis/sclerosis involving less than $50 \%$ of the glomerular tuft; grade 3 , diffuse 
glomerular hyalinosis/sclerosis involving more than $50 \%$ of the tuft; grade 4, diffuse glomerulosclerosis with total tuft obliteration and collapse. The resulting index in each animal was expressed as a mean of all scores obtained.

Tubulointerstitial and vascular damage was assessed on Periodic Acid Schiff (PAS) stained paraffin sections at a magnification of $\times 100$ using a similar scoring system [19]. For determination of the tubulointerstitial damage score, 10 fields per kidney were randomly sampled and the changes (0-4) were graded as follows: grade 0 , no change; grade 1 , lesions involving less than $25 \%$ of the area; grade 2, lesions affecting 25 to $50 \%$; grade 3 , lesions involving more than $50 \%$ and grade 4 involving (almost) the entire area. Similarly, for the vascular damage score the following scheme was adopted: grade 0: no wall thickening, grade 1: mild wall thickening, grade 2: moderate wall thickening, grade 3: severe wall thickening, grade 4: fibrinoid necrosis of the vascular wall.

Glomerular geometry. Area $\left(\mathrm{A}_{\mathrm{A}}\right)$ and volume density $\left(\mathrm{V}_{\mathrm{V}}\right)$ of the renal cortex and medulla as well as the number of glomeruli per area $\left(\mathrm{N}_{\mathrm{A}}\right)$ were measured using a Zeiss eyepiece (Integrationsplatte II; Zeiss, Oberkochen, Germany) and the point counting method $\left(\mathrm{P}_{\mathrm{P}}=\mathrm{A}_{\mathrm{A}}=\mathrm{V}_{\mathrm{V}}\right)$ at a magnification of $\times 400$. The number of glomeruli per area $\left(\mathrm{N}_{\mathrm{A}}\right)$ was then corrected for tissue shrinkage $\left(1.08^{2}\right)$. Total cortex volume $\left(\mathrm{V}_{\text {cortex }}\right)$ was derived from kidney mass divided by specific weight of the kidney $\left(1.04 \mathrm{~g} / \mathrm{cm}^{3}\right)$ times the volume density of the cortex. Glomerular geometry was analysed as follows: volume density $\left(\mathrm{V}_{\mathrm{V}}\right)$ of glomeruli and tubulointerstitium as well as the area density of the glomerular tuft $\left(\mathrm{A}_{\mathrm{AT}}\right)$ were measured by point counting according to $\mathrm{P}_{\mathrm{P}}=\mathrm{A}_{\mathrm{A}}=\mathrm{V}_{\mathrm{V}}[20,21]$ at a magnification of $\times 400$ on $\mathrm{HE}$ sections. Total area of glomerular tuft $\left(\mathrm{A}_{\mathrm{T}}\right)$ was then calculated as $\mathrm{A}_{\mathrm{T}}=\mathrm{A}_{\mathrm{AT}} \times \mathrm{A}_{\text {cortex }}$. The number of glomeruli per volume $\left(\mathrm{N}_{\mathrm{V}}\right)$ was derived from glomerular area density $\left(\mathrm{N}_{\mathrm{A}}\right)$ and the volume density $\left(\mathrm{V}_{\mathrm{V}}\right)$ of glomerular using the formula: $\mathrm{N}_{\mathrm{V}}=\mathrm{k} / \beta \times \mathrm{N}_{\mathrm{A}} 1.5 / \mathrm{V}_{\mathrm{V}}{ }^{0.5}$ with $\mathrm{k}=1.1$ (size distribution coefficient) and $\beta=1.382$ (shape coefficient for spheres). The total number of glomeruli was calculated from the total volume of the renal cortex and the number of glomeruli per cortex volume: $\mathrm{N}_{\text {glom }}=\mathrm{N}_{\mathrm{V}} \times \mathrm{V}_{\text {Cortex. }}$ The mean glomerular tuft volume was calculated according to $\mathrm{v}=\beta / \mathrm{k} \times \mathrm{A}_{\mathrm{T}}^{1.5}$ with $\beta=1.382$ and $\mathrm{k}=1.1$ $[22,23]$.

Analysis of glomerular cell number and volume. In five semithin sections per animal glomerular cell number and volume were analysed using the point counting method and a 100 point eyepiece (Integrationsplatte II, Zeiss, Oberkochen Germany) at a magnification of $\times 1000$ (oil immersion) [22, 23]. Briefly, glomerular cell number (podocytes, mesangial and endothelial cells) was calculated in at least 30 glomeruli per animal from cell density per volume $\left(\mathrm{Nc}_{\mathrm{v}}\right)$ and volume density of the respective cell type $\left(\mathrm{Vc}_{\mathrm{v}}\right)$ according to the equation: $\mathrm{Nc}_{\mathrm{v}}=\mathrm{k} / \beta \times \mathrm{Nc}_{\mathrm{A}}{ }^{1.5} / \mathrm{Vc}_{\mathrm{v}}{ }^{0.5}$ with $\beta$ for podocytes $=1.5$ and for mesangial and endothelial cells $=1.4$ and $\mathrm{k}=1[22,23]$. The respective cell volume was calculated with $\mathrm{V}_{\mathrm{c}}=\mathrm{Vc}_{\mathrm{v}} \times \mathrm{V}_{\text {glom }}$.

Analysis of tubulointerstitial volume. Area $\left(\mathrm{A}_{\mathrm{int}}\right)$ and volume density $\left(\mathrm{V}_{\text {int }}\right)$ of the tubulointerstitium were measured using a Zeiss eyepiece (Integrationsplatte II; Zeiss, Oberkochen, Germany) and the point counting method $\left(\mathrm{P}_{\mathrm{P}}=\mathrm{A}_{\mathrm{A}}=\mathrm{V}_{\mathrm{V}}\right)$ at a magnification of $\times 25: V_{\text {int }}=V_{N} \times V_{\text {vint }}$ [24].

Immunohistological investigations. Immunohistochemical staining for PCNA and p2 $7^{\mathrm{KIP} 1}$ was evaluated using light microscopy at a magnification of $\times 400$. In 50 glomeruli per kidney the number of PCNA and $\mathrm{p} 27 \mathrm{KIP} 1$ positive cells per glomerulus as well as per glomerular and per tubulointerstitial area were counted. Immunohistological stains using antibodies against TGF- $\beta_{1}$, ET-1, fibronectin, $\alpha$-smooth muscle actin and PDGF were analysed by two investigators blinded with respect to the animal group using the following semiquantitative scoring system (0-4): score 0: no expression, score 1: weak expression, score 2: moderate expression, score 3: strong expression, score 4: extremely strong expression. In a number of animals $(n=5)$ per group desmin positivity of podocytes and actin positivity of mesangial cells were investigated as markers of cell degeneration and activation, respectively. For analysis of desmin immunohistochemistry the capillary tuft was divided into four quarters and the following scoring system was used: score 0: no expression, score 1: desmin positive cells in one quarter, score 2: desmin positive cells in two quarters, score 3: desmin positive cells in three quarters and score 4: desmin positive cells all over the capillary tuft. The damage score was then calculated as: [(0score 0 )+ score $1+$ score $2+$ score $3+$ score 4$): 5]+15$.

In situ hybridisation. Non radioactive in situ hybridisation using ET-1 sense and antisense probes was carried out in five animals per group $[25,26]$. Briefly, cryostat sections $(10 \mu \mathrm{m})$ were fixed with $3 \%$ paraformaldehyde/phosphate buffered saline (PBS, $5 \mathrm{~min}, 4^{\circ} \mathrm{C}, \mathrm{pH} 7.0$ ). Subsequently, the sections were dehydrated, air-dried, and stored at $-20^{\circ} \mathrm{C}$.

Probe preparation and labelling. A $340 \mathrm{bp}$ cDNA fragment of the ET-1 cDNA was obtained from a PCR product using rat ET-1 specific primers after reverse transcriptation of rat kidney total RNA [27]. The segment encoding positions 222 to 561 of the rat ET-1 gene was inserted into the pGEM-T vector system (Promega Biotech., Madison, USA). For preparation of the antisense RNA probe, the plasmid was linearised with Spe I and transcribed using T7 Bacteriophage RNA polymerase. Linearization of the plasmid with Nco I and transcription with SP6 RNA Polymerase generated the sense RNA probe. Digoxigenin-labelled RNA probes were synthesized using a DIG RNA labelling mix (Boehringer Mannheim, Mannheim, Germany). The sections were hybridised with $4 \mathrm{ng}$ of labelled probe in buffer in a moist chamber. Hybridisation of the probe with native mRNA was allowed for $18 \mathrm{~h}$ at $50^{\circ} \mathrm{C}$. Afterwards, several post hybridisation steps were carried out. After post hybridisation washes, the sections were equilibrated in buffer I [25]. Non-specific background staining was blocked by incubation for $1 \mathrm{~h}$ with $0.5 \%$ blocking reagent/buffer I (Boehringer Mannheim, Germany) [25]. The hybridisation products were visualised by enzyme-linked immunoassay using alkaline phosphataseconjugated sheep anti-digoxigenin-Fab fragments $(750 \mathrm{U} / \mathrm{ml}$, Boehringer Mannheim, Germany,). Following incubation at $4^{\circ} \mathrm{C}$ overnight, unbound conjugate was removed by two washes in buffer I followed by equilibration of the sections in buffer II [25]. Nitro-blue tetra-zolium (NBT) and 5-bromo-4-chloro3-indolyl phosphate (BCIP) served as chromogens. Negative controls included hybridisation with the sense RNA probe, incubation without probe for detection of unspecific binding of the primary antibody and omission of both probe and primary antibody. Staining intensity was analysed using the previously described semiquantitative scoring system (scores 0-4) [28].

Statistics. Data are given as means \pm SD. After testing for normality, Kruskal-Wallis test or one-way ANOVA, respectively, were chosen for analysis of variance, followed by Duncan's multiple-range test to calculate whether the differences between the groups were significant. The results were considered significant when the $p$ value was less than 0.05 .

Changes of desmin positivity are given as means \pm range and the differences were analysed using Mann Whitney $U$ test $(p<0.05)$. 
Table 1. Animal data (after termination of the experiment)

\begin{tabular}{|c|c|c|c|c|c|c|}
\hline & $\begin{array}{l}\text { non-diabetic } \\
\text { control } \\
{[n=8]}\end{array}$ & $\begin{array}{l}\text { untreated } \\
\text { diabetes } \\
{[n=10]}\end{array}$ & $\begin{array}{l}\text { diabetes }+ \\
\mathrm{ET}_{\mathrm{A}}-\mathrm{RB} \\
{[n=9]}\end{array}$ & $\begin{array}{l}\text { diabetes } \\
+ \text { ACE-i } \\
{[n=12]}\end{array}$ & $\begin{array}{l}\text { diabetes } \\
+ \text { combi } \\
{[n=12]}\end{array}$ & ANOVA \\
\hline kidney weight $[\mathrm{g}]$ & $2.2 \pm 0.3$ & $2.7 \pm 0.4 *$ & $2.5 \pm 0.35 *$ & $2.3 \pm 0.4$ & $2.4 \pm 0.3$ & $p<0.05$ \\
\hline blood glucose [mg/dl] & $185 \pm 43$ & $650 \pm 104 *$ & $569 \pm 48 *$ & $527 \pm 125^{*}$ & $564 \pm 69 *$ & $p<0.05$ \\
\hline $\mathrm{HbA}_{1 \mathrm{c}}[\%]$ & $5 \pm 0.2$ & $9.7 \pm 0.5^{*}$ & $9.4 \pm 1.3 *$ & $9.2 \pm 1.2 *$ & $9.8 \pm 1.2 *$ & $p<0.05$ \\
\hline albuminuria $[\mathrm{mg} / 24 \mathrm{~h}]$ & $0.48 \pm 0.15$ & $1.73 \pm 0.56^{*}$ & $1.06 \pm 0.38$ & $0.68 \pm 0.11^{+}$ & $0.56 \pm 0.15^{+}$ & $p<0.05$ \\
\hline
\end{tabular}

$* p<0.05$ vs. non-diabetic control

${ }^{+} p<0.05$ vs. untreated diabetes

Table 2. Indices of renal damage and glomerular geometry

\begin{tabular}{|c|c|c|c|c|c|c|}
\hline & $\begin{array}{l}\text { non-diabetic } \\
\text { control } \\
{[n=8]}\end{array}$ & $\begin{array}{l}\text { untreated } \\
\text { diabetes } \\
{[n=10]}\end{array}$ & $\begin{array}{l}\text { diabetes } \\
+\mathrm{ET}_{\mathrm{A}}-\mathrm{RB} \\
{[n=9]}\end{array}$ & $\begin{array}{l}\text { diabetes } \\
+ \text { ACE-i } \\
{[n=12]}\end{array}$ & $\begin{array}{l}\text { diabetes } \\
+ \text { combi } \\
{[n=12]}\end{array}$ & ANOVA \\
\hline tubulointerstitial damage index & $0.12 \pm 0.05$ & $0.38 \pm 0.1 *$ & $0.24 \pm 0.08 *$ & $0.17 \pm 0.1 *+$ & $0.17 \pm 0.1^{*+}$ & $p<0.05$ \\
\hline vascular damage index & $0.03 \pm 0.03$ & $0.27 \pm 0.04 *$ & $0.12 \pm 0.04 *+$ & $0.14 \pm 0.04 *+$ & $0.14 \pm 0.03^{*+}$ & $p<0.05$ \\
\hline $\begin{array}{l}\text { total number of glomeruli } \\
\text { per one kidney }\end{array}$ & $46152 \pm 17094$ & $36438 \pm 5683$ & $48848 \pm 9320$ & $40510 \pm 9594$ & $36476 \pm 2284$ & n.s. \\
\hline tubulointerstitial volume $\left[\mathrm{cm}^{3}\right]$ & $1.62 \pm 0.28^{+}$ & $2.00 \pm 0.31 *$ & $1.92 \pm 0.15 *$ & $1.59 \pm 0.2^{+}$ & $1.68 \pm 0.28^{+}$ & $p<0.05$ \\
\hline
\end{tabular}

$* p<0.05$ vs. non-diabetic control

${ }^{+} p<0.05$ vs. untreated diabetes

Table 3. Number and volume of glomerular cells

\begin{tabular}{|c|c|c|c|c|c|c|}
\hline & $\begin{array}{l}\text { non-diabetic } \\
\text { control } \\
{[n=8]}\end{array}$ & $\begin{array}{l}\text { untreated } \\
\text { diabetes } \\
{[n=10]}\end{array}$ & $\begin{array}{l}\text { diabetes } \\
+\mathrm{ET}_{\mathrm{A}}-\mathrm{RB} \\
{[n=9]}\end{array}$ & $\begin{array}{l}\text { diabetes } \\
+ \text { ACE-i } \\
{[n=12]}\end{array}$ & $\begin{array}{l}\text { diabetes } \\
+ \text { combi } \\
{[n=12]}\end{array}$ & ANOVA \\
\hline mean podocyte volume $\left[\mu \mathrm{m}^{3}\right]$ & $63099 \pm 1015^{+}$ & $72172 \pm 5930^{*}$ & $71193 \pm 9899$ & $62313 \pm 1126^{+}$ & $52754 \pm 1175^{+}$ & $\mathrm{p}<0.05$ \\
\hline $\begin{array}{l}\text { mesangial cell number } \\
\text { per glomerulus }\end{array}$ & $224 \pm 64^{+}$ & $358 \pm 82^{*}$ & $254 \pm 104$ & $227 \pm 16^{+}$ & $223 \pm 75^{+}$ & $\mathrm{p}<0.05$ \\
\hline
\end{tabular}

${ }^{*} p<0.05$ vs. non-diabetic control; ${ }^{+} p<0.05$ vs. untreated diabetes; $\# p<0.05$ vs. diabetes + combi

\section{Results}

Animal data. Diabetic rats had stable, moderate hyperglycaemia throughout the 6 months of the study with a mean blood glucose concentration of $650 \pm 104 \mathrm{mg} / \mathrm{dl}$ and a mean $\mathrm{HbA}_{1 \mathrm{c}}$ of $9.7 \pm 0.5 \%$ (Table 1). Blood glucose levels were not modified by either ACE-i or $\mathrm{ET}_{\mathrm{A}}-\mathrm{RB}$ treatment. Despite increased food intake $(58 \pm 6 \mathrm{~g} /$ day $)$ in diabetic rats compared to non-diabetic rats $(37 \pm 3 \mathrm{~g} /$ day), body weight was lower in diabetic rats. Body weight, food or water in- take were not modified by treatment with ACE-i nor $\mathrm{ET}_{\mathrm{A}}-\mathrm{RB}$, respectively. Despite lower body weight, kidney weight was higher in both untreated and $\mathrm{ET}_{\mathrm{A}^{-}}$ $\mathrm{RB}$ treated diabetic animals compared to non-diabetic control rats. Serum cholesterol and LDL cholesterol concentrations were not different between the experimental groups (data not shown). Serum triglyceride concentrations were higher in untreated diabetic rats $(374 \pm 215 \mathrm{mg} / \mathrm{dl})$ than in non-diabetic controls $(94 \pm 31 \mathrm{mg} / \mathrm{dl})$ and treated diabetic animals $(223 \pm 146$ in $\mathrm{ET}_{\mathrm{A}}-\mathrm{RB}$ treated animals, $159 \pm 100$ in ACE-i treat- 


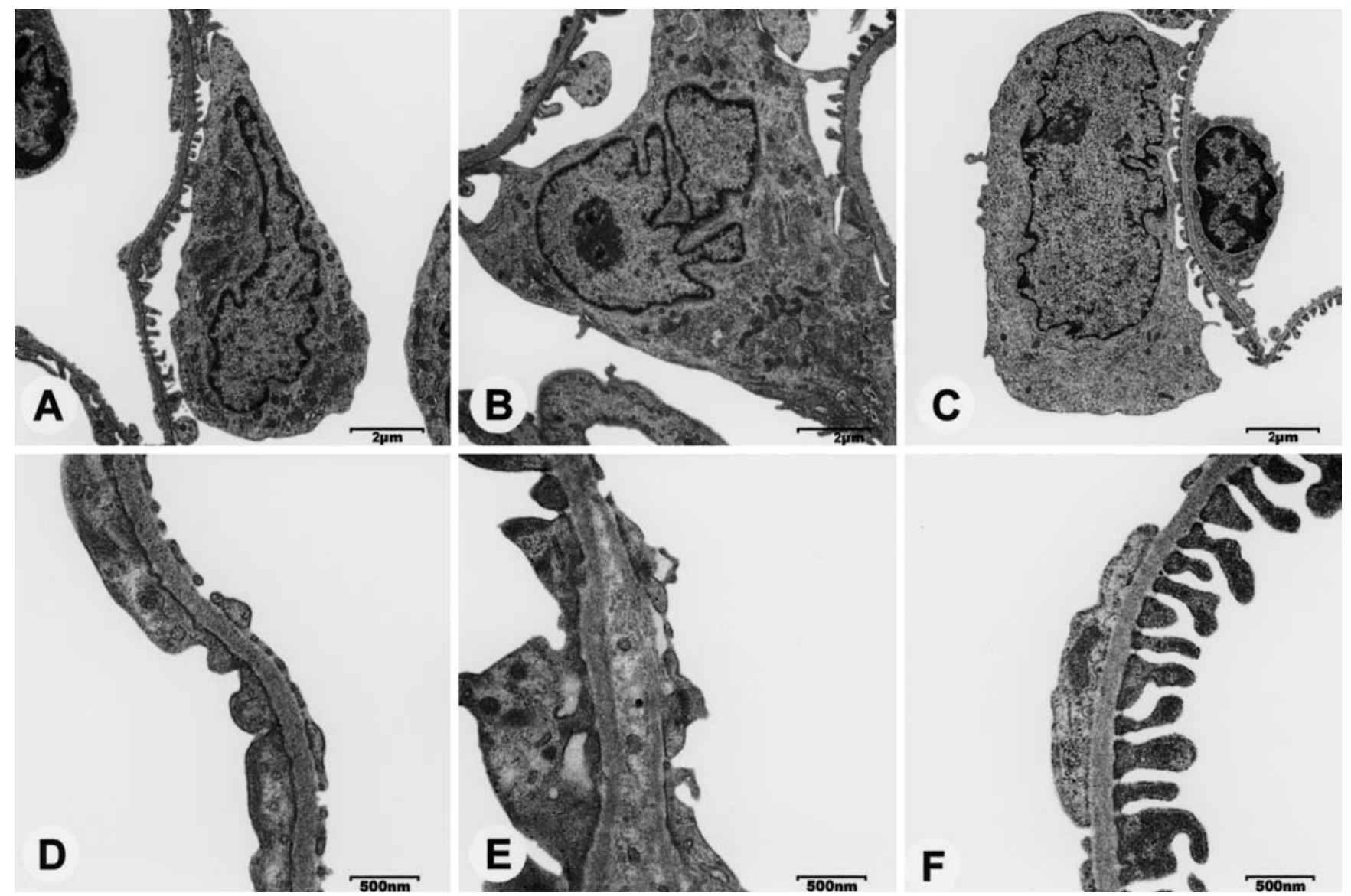

Fig. 1A-F. Glomerular ultrastructure in untreated and treated diabetic rats. (A) Podocyte of an untreated non-diabetic control, (B) Untreated diabetic rat with podocyte hypertrophy and partial fusion of foot processes, (C) ACE-i treated diabetic rat with normal sized podocyte, (D) Glomerular basement mem- brane (GBM) of an untreated non-diabetic control, (E) Untreated diabetic rat with moderate thickening of the GBM, $(\mathbf{F})$ ACE-i treated diabetic rat with preservation of normal thickness of the GBM

Table 4. Number of PCNA positive glomerular and tubulointerstitial cells as well as number of p27 positive glomerular cells

\begin{tabular}{|c|c|c|c|c|c|c|}
\hline & $\begin{array}{l}\text { non-diabetic } \\
\text { control } \\
{[n=8]}\end{array}$ & $\begin{array}{l}\text { untreated } \\
\text { diabetes } \\
{[n=10]}\end{array}$ & $\begin{array}{l}\text { diabetes } \\
+\mathrm{ET}_{\mathrm{A}}-\mathrm{RB} \\
{[n=9]}\end{array}$ & $\begin{array}{l}\text { diabetes } \\
+ \text { ACE-i } \\
{[n=12]}\end{array}$ & $\begin{array}{l}\text { diabetes } \\
+ \text { combi } \\
{[n=12]}\end{array}$ & ANOVA \\
\hline $\begin{array}{l}\text { PCNA positive cells } \\
\text { per mm of tubulointerstitial area }\end{array}$ & $0.69 \pm 0.24^{+}$ & $6.99 \pm 3.93 *$ & $5.25 \pm 2.41 *$ & $2.32 \pm 1.16^{*+}$ & $0.42 \pm 0.15^{+}$ & $\mathrm{p}<0.05$ \\
\hline
\end{tabular}

${ }^{*} p<0.05$ vs. non-diabetic control; ${ }^{+} p<0.05$ vs. untreated diabetes

ed animals and $124 \pm 65 \mathrm{mg} / \mathrm{dl}$ in rats given the combination treatment).

After 6 months, systolic blood pressure (bp) was higher in untreated diabetic animals compared to nondiabetic controls and was lower in ACE-i and ACE-i $+\mathrm{ET}_{\mathrm{A}}-\mathrm{RB}$ treated animals. In diabetic animals treated with the $\mathrm{ET}_{\mathrm{A}}-\mathrm{RB}$, bp ranged between untreated and ACE-i treated diabetic rats, but was still lower than in untreated diabetic controls.
Urinary albumin excretion was higher in untreated diabetic animals. Urinary albumin excretion was reduced by ACE-i treatment alone and in combination with $\mathrm{ET}_{\mathrm{A}}-\mathrm{RB}$, but not with the $\mathrm{ET}_{\mathrm{A}}-\mathrm{RB}$ alone.

Morphological investigations. Moderate glomerulosclerosis was noted in this standard model of experimental diabetic nephropathy. After 6 months moderate diffuse expansion of the mesangium and segmental 

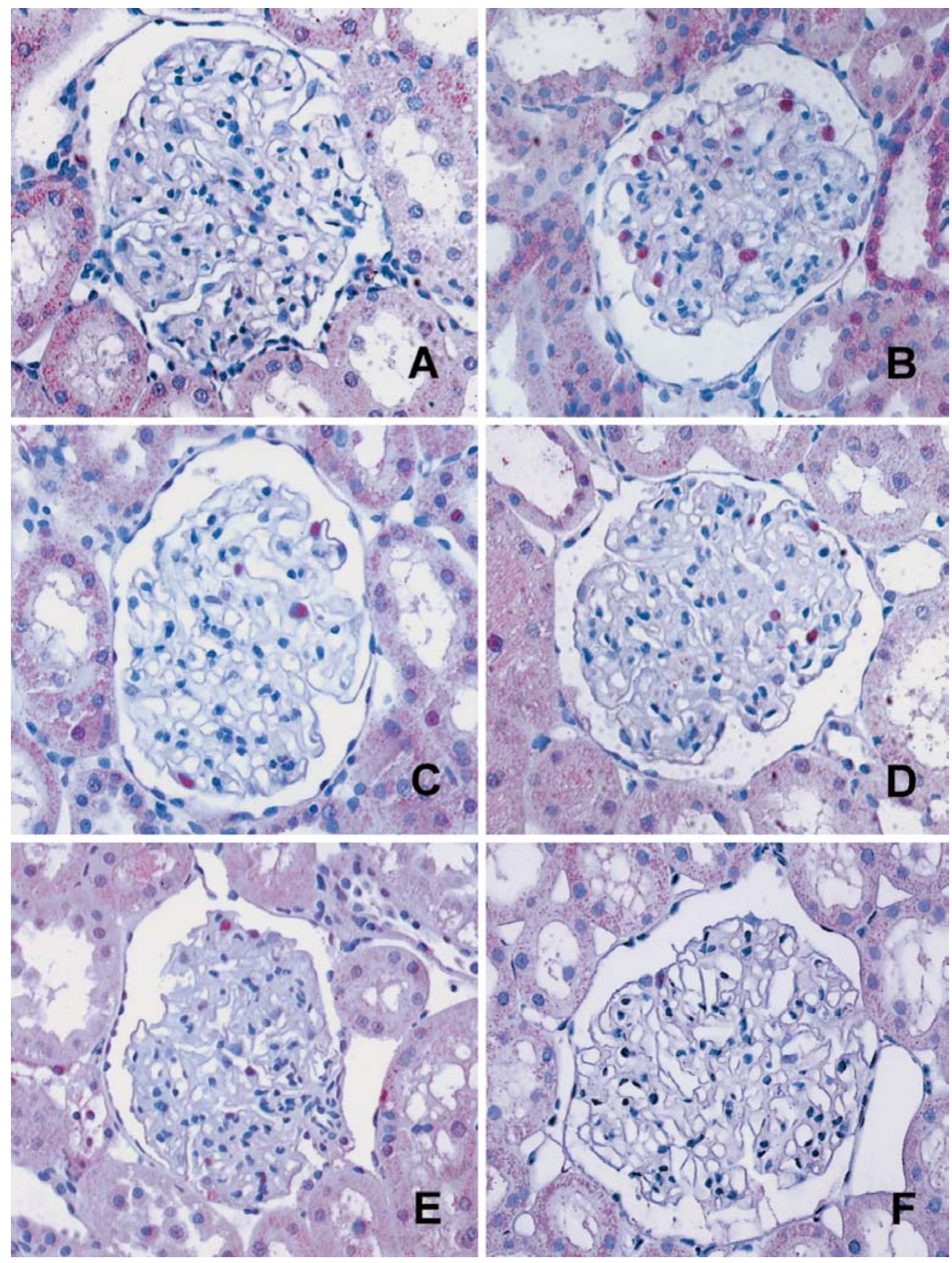

Fig. 2A-F. Effect of ACE-i and $\mathrm{ET}_{\mathrm{A}}-\mathrm{RB}$ on p27 positivity of glomerular cells (Immunohistochemistry, mag.: 1:300). (A) Non-diabetic control rat with virtually no p27 positive cells. (B) Untreated diabetic control rat with numerous p27 positive glomerular cells. (C) $\mathrm{ET}_{\mathrm{A}}-\mathrm{RB}$ treated diabetic rat with less p27 positive glomerular cells than in panel B. (D) ACE-i treated diabetic rat with only a few p27 positive glomerular cells. (E) Diabetic rat treated with a combination of ACE-i $+E^{-} T_{A}-R B$ and also only a few p27 positive glomerular cells. (F) Control (omission of first antibody)

glomerular hypercellularity were seen, but marked mesangiolysis or nodular sclerosis were not observed. Indices of glomerulosclerosis and of vascular damage were higher in all diabetic groups than in non-diabetic controls (Table 2). They were lower, however, in all three treated diabetic groups compared to untreated diabetic rats.

The tubulointerstitial damage index was also higher in untreated diabetic rats compared to non-diabetic controls. It was lower in groups with ACE-i and combination treatment, but not in the $\mathrm{ET}_{\mathrm{A}}-\mathrm{RB}$ treated diabetic rats.

Mean glomerular volume was higher in untreated diabetic animals compared to non-diabetic controls and was lower in all diabetic intervention groups. The 
A Effect of ACE-i and $\mathrm{ET}_{\mathrm{A}}-\mathrm{RB}$ expression of ET-1 on the protein level glomerular ET-1 staining vascular ET-1 staining
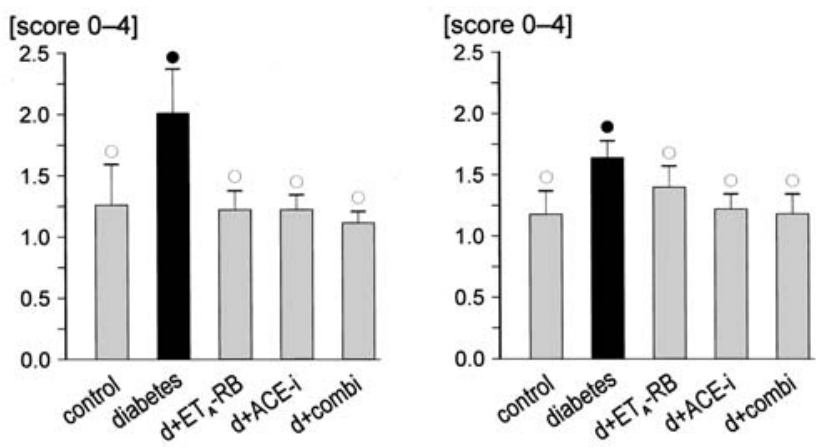

B

Effect of $A C E-i$ and $E T_{A}-R B$ expression of fibronectin on the protein level tubulointerstitial fibronectin staining vascular fibronectin staining
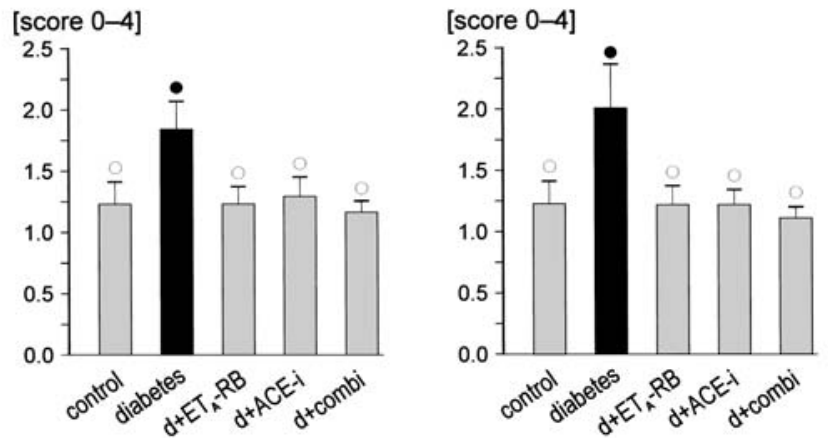

C

Effect of ACE-i and $E T_{A}-R B$ on protein expression of PDGF-AB glomerular PDGF staining

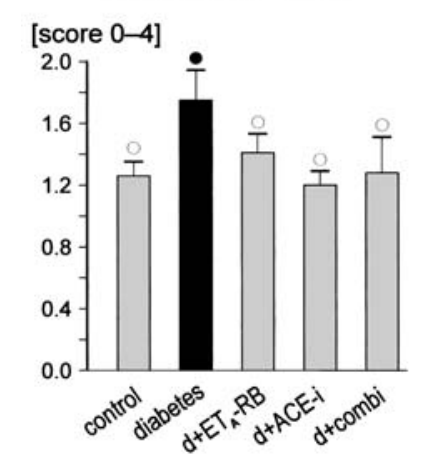
tubulointerstitial PDGF staining vascular PDGF staining
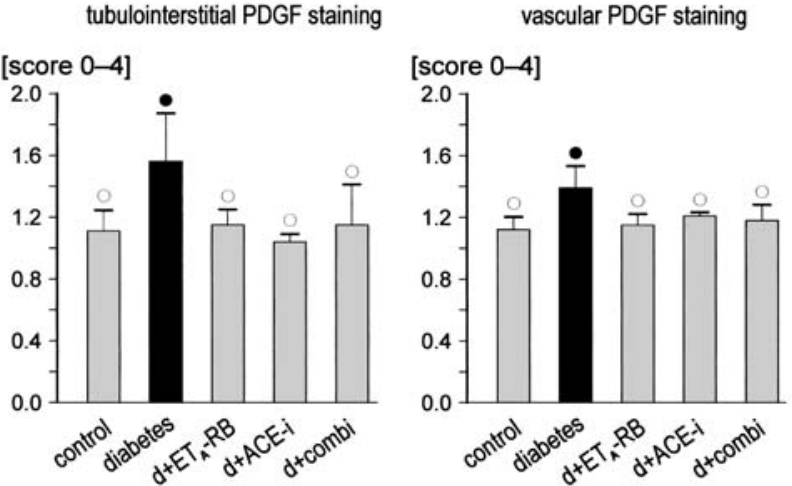

D Effect of ACE-i and $E T_{A}-R B$ on protein expression of TGF- $\beta_{\text {, }}$ glomerular TGF- $\beta$, staining tubulointerstitial TGF- $\beta_{1}$ staining
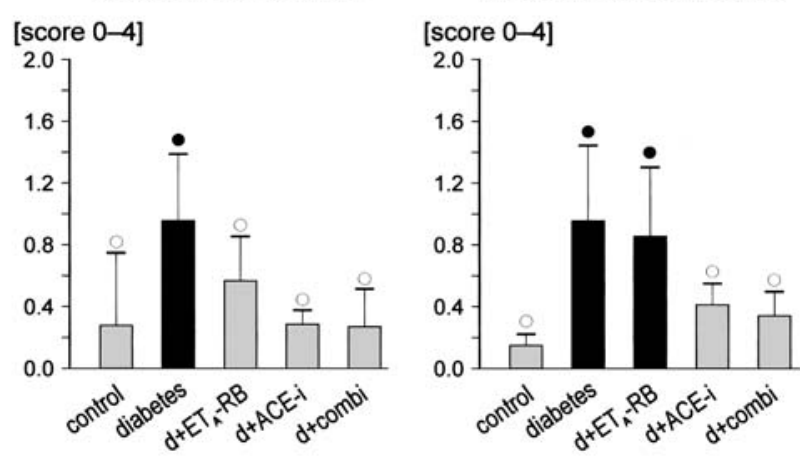


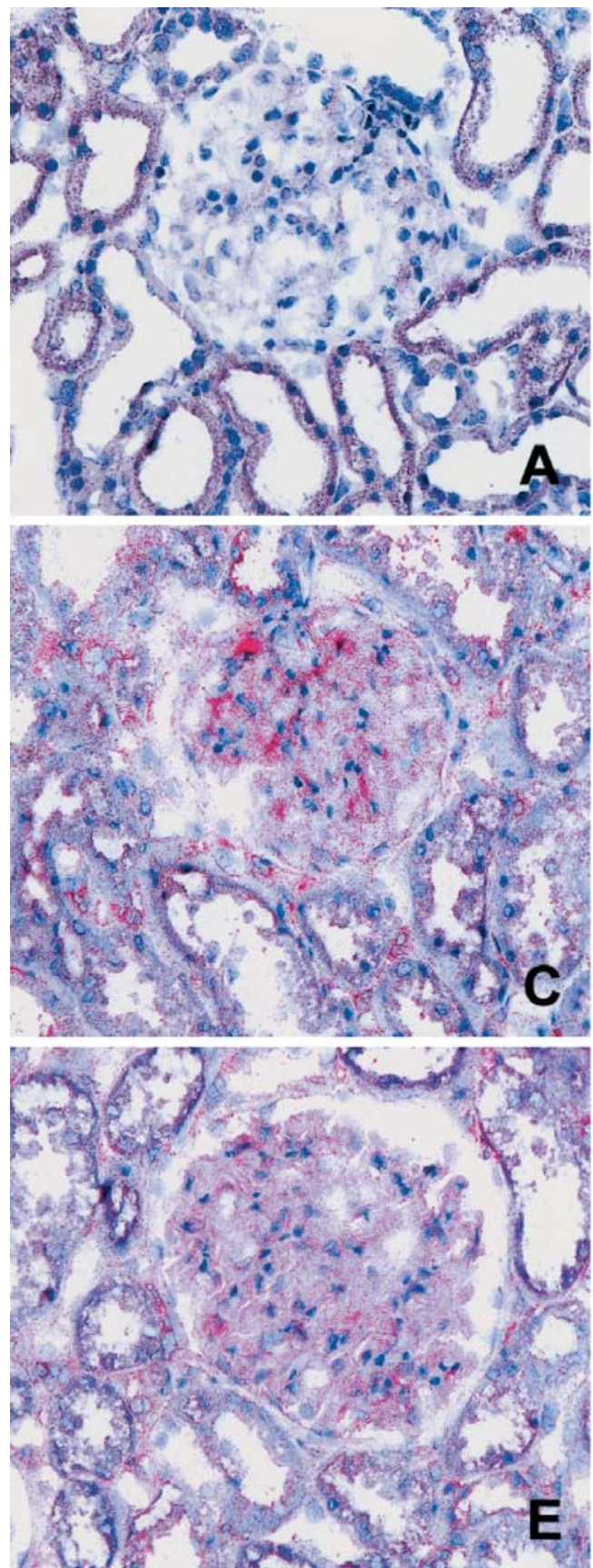

4 Fig. 3A-D. Effect of ACE-i and $\mathrm{ET}_{\mathrm{A}}-\mathrm{RB}$ on expression of ET-1, fibronectin, PDGF-AB and TGF- $\beta_{1}$ on the protein level. $p<0.05$ vs. non diabetic controls, $\bigcirc p<0.05$ vs. untreated diabetic control. (A) ET-1 protein expression was higher in glomerular and endothelial cells of untreated diabetic animals and was less intense in all treatment groups. (B) The expression of fibronectin was marked in tubulointerstitial and endothelial cells of untreated diabetic STZ rats and was less intense in all intervention groups. (C) In untreated diabetic rats PDGF expression on the protein level was higher in glomerular, tubulointerstitial and endothelial cells than in non-diabetic rats. Expression was less intense in all intervention groups. (D) Glomerular TGF- $\beta 1$ expression was higher in untreated diabetic rats and in contrast was lower in all treatment groups. Increased tubulointerstitial expression in diabetic rats was lowered by ACE-i alone or in combination of ACE-i and $\mathrm{ET}_{\mathrm{A}}$ - $\mathrm{RB}$ treatment

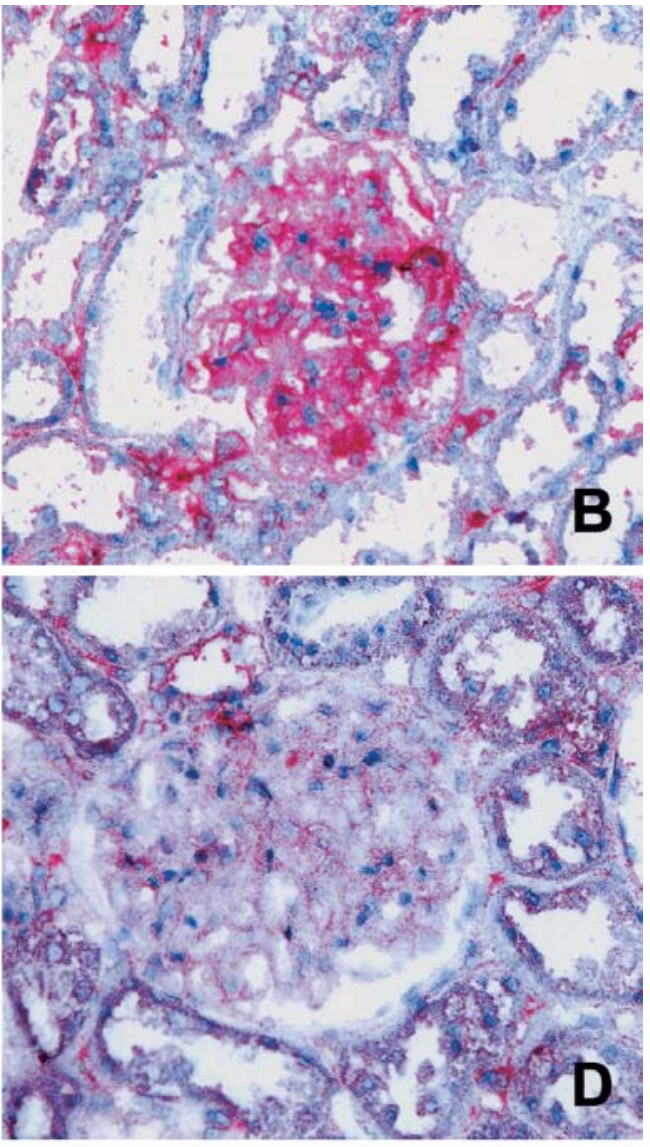

Fig. 4A-E. Effect of ACE-i and $\mathrm{ET}_{\mathrm{A}}-\mathrm{RB}$ on glomerular endothelin-1 protein expression (Immunohistochemistry, mag. 1:300). (A) Non-diabetic control rat with virtually very low glomerular endothelin-1 expression. (B) Untreated diabetic control rat with increased glomerular endothelin-1 expression. (C) $\mathrm{ET}_{\mathrm{A}}-\mathrm{RB}$ treated diabetic rat with less glomerular endothelin-1 expression. (D) ACE-i treated diabetic rat with decreased glomerular endothelin-1 expression. (E) Diabetic rat treated with a combination of $\mathrm{ACE}-\mathrm{i}+\mathrm{ET}_{\mathrm{A}}-\mathrm{RB}$ and also only low glomerular endothelin-1 expression

total number of glomeruli per kidney was similar in all experimental groups.

Mean tubulointerstitial volume was higher in untreated diabetic rats than in non-diabetic rats. Only ACE-i alone and in combination led to lower values whereas $\mathrm{ET}_{\mathrm{A}}-\mathrm{RB}$ had no influence.

The mean number of podocytes per glomerulus was lower in diabetic rats than in non-diabetic controls (Table 3 ). In parallel, mean podocyte volumes were higher. This loss of podocytes was prevented by ACE-i alone or in combination with $\mathrm{ET}_{\mathrm{A}}-\mathrm{RB}$. The mean number of mesangial and endothelial cells was higher in untreated diabetic animals compared to non-diabetic controls. Mesangial cell hyperplasia was prevented only by ACE-i and combination whereas endothelial cell hyperplasia was prevented by all three interventions. Mesangial cell volume was 


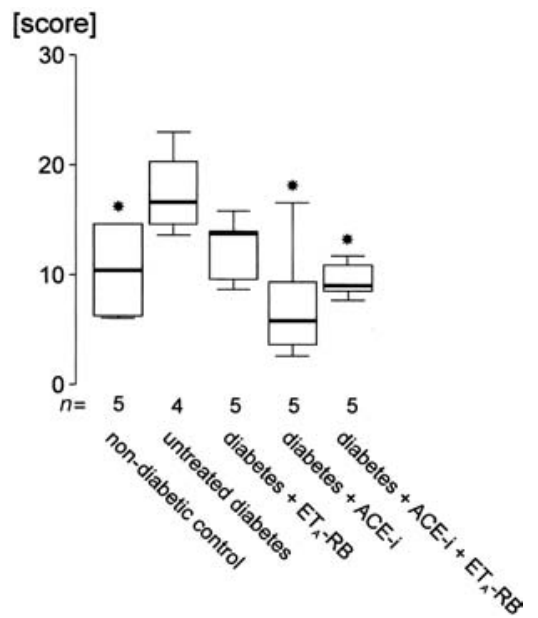

Fig. 5. Effect of ACE-i and $\mathrm{ET}_{\mathrm{A}}-\mathrm{RB}$ on desmin positivity of podocytes. Desmin positive podocytes were more frequent in untreated diabetic rats than in controls, ACE-i and combination treated animals. ${ }^{*} p<0.05$ vs untreated diabetes

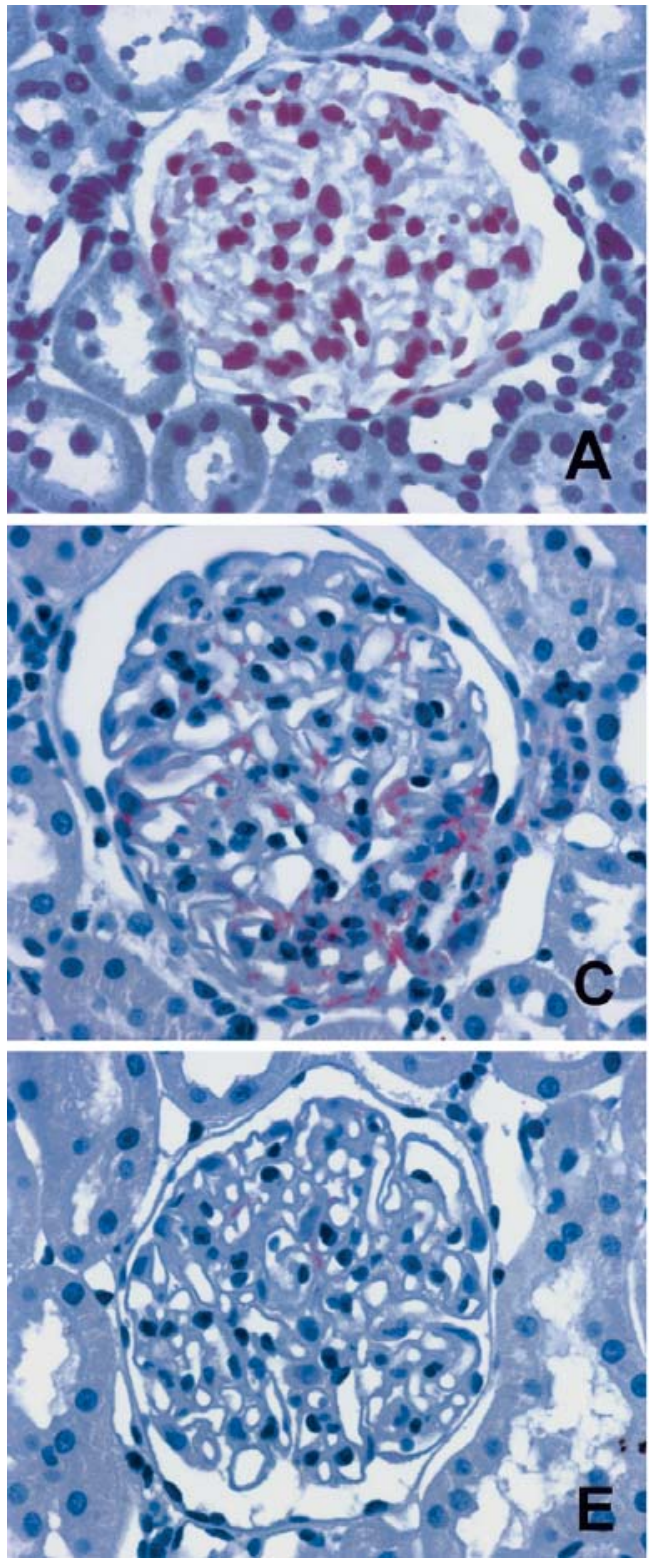

higher in untreated diabetic rats than in non-diabetic controls and was lower in the ACE- $i$ and combination treated group. In contrast, endothelial cell volume was not different between the experimental groups (data not shown).

Using electron microscopy, podocyte hypertrophy and partial fusion of foot processes were seen in untreated diabetic rats (Fig. 1B) compared to normal sized podocytes of untreated non-diabetic control (Fig. 1A) and ACE-i treated diabetic rats (Fig. 1C). Moderate thickening of the glomerular basement membrane was found in untreated diabetic rats (Fig. 1E) compared to non-diabetic controls (Fig. 1 D) and ACE-i treated rats (Fig. 1F).

Immunohistochemical investigations. PCNA (Table 4): Proliferation and / or activation of glomerular and tubulointerstitial cells was assessed using an antibody against PCNA. Untreated diabetic animals had

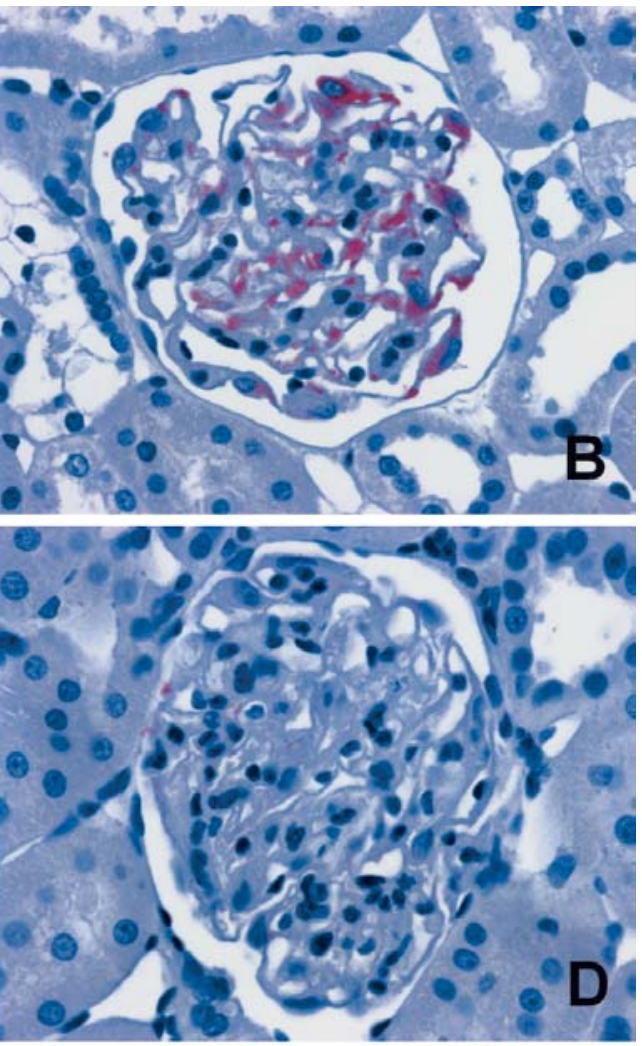

Fig. 6A-E. Podocyte damage in untreated and treated STZ diabetic rats assessed by desmin immunohistochemistry (Immunohistochemistry, mag. 1:300). (A) Untreated non-diabetic control rat. No desmin staining of podocytes. (B) Untreated diabetic rat. Note marked cytoplasmatic desmin expression in hypertrophied podocytes. (C) In $\mathrm{ET}_{\mathrm{A}}-\mathrm{RB}$ treated diabetic rats desmin staining of podocytes was less pronounced but still detectable. (D) ACE-i treated diabetic rat fails to exhibit desmin staining of podocytes. (E) ACE-i and $\mathrm{ET}_{\mathrm{A}}-\mathrm{RB}$ treated diabetic rat without desmin staining of podocytes 
Effect of ACE-i and $E T_{A}-R B$ on endothelin-1 mRNA expression
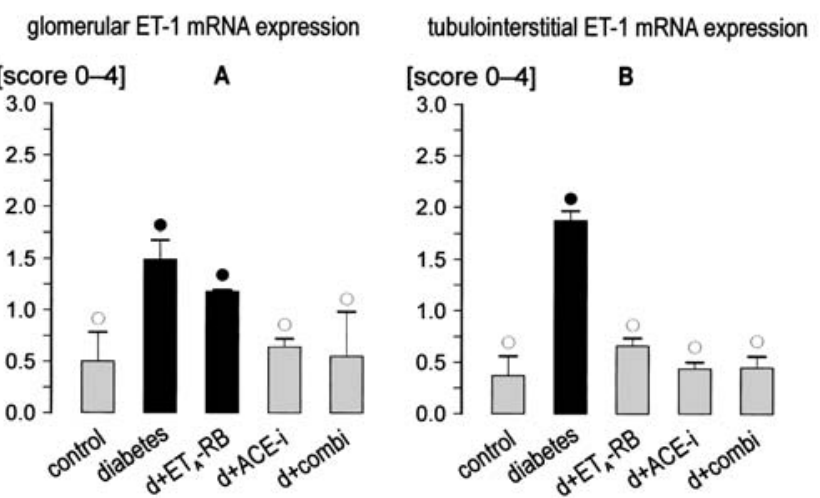

Fig. 7A, B. Semiquantitative evaluation of the effect of ACE-i and $\mathrm{ET}_{\mathrm{A}}-\mathrm{RB}$ on glomerular and tubulointerstitial ET-1 mRNA expression (non radioactive in-situ hybridisation). $p<0.05$ vs. non diabetic controls, $\bigcirc p<0.05$ vs. untreated diabetic control. (A) Glomerular ET-1 mRNA is markedly increased in untreated diabetic rats compared to non-diabetic controls; it is lower in the ACE-i or combination treated diabetic animals. (B) Expression of ET-1 mRNA in the tubulointerstitium was increased in untreated diabetic STZ rats compared to sham operated controls and was lower in all treatment groups

more PCNA positive cells per glomerular profile, mainly podocytes, than non-diabetic controls. All treatments led to lower values. In addition, the number of PCNA positive cells per $\mathrm{mm}^{2}$ of capillary tuft was higher in untreated diabetic rats $(0.71 \pm 0.51)$ than in non-diabetic controls $(0.21 \pm 0.17)$ and was lower in all three treatment groups. The number of PCNA positive tubulointerstitial cells per view field was higher in untreated diabetic animals $(1.04 \pm 0.37)$ compared to nondiabetic rats $(0.09 \pm 0.03)$. Treatment with the ACE-i and in particular with the combination prevented proliferation and/or activation of tubulointerstitial cells $(0.5 \pm 0.12$ in ACE-i and $0.07 \pm 0.05$ in combination treatment). In contrast, $\mathrm{ET}_{\mathrm{A}}-\mathrm{RB}$ treated diabetic rats $(0.87 \pm 0.59)$ showed no difference compared with untreated diabetic rats. The same was true for the number of PCNA positive cells per $\mathrm{mm}^{2}$ of tubulointerstitial area.

The effect of ACE-i and $\mathrm{ET}_{\mathrm{A}}-\mathrm{RB}$ on p27 KIP1 cell positivity is shown in Table 4 and illustrated in Fig. 2. The absolute and relative number of p27 KIP1 positive cells, mainly podocytes, was higher in untreated diabetic animals (B) than in non-diabetic controls (A) and was lower in all treatment groups $(\mathrm{C}-\mathrm{E})$.

The effect of ACE-i and $\mathrm{ET}_{\mathrm{A}}-\mathrm{RB}$ on renal ET-1 expression on the protein level. ET-1 protein expression was more intense in mesangial cells and podocytes, vascular smooth muscle and endothelial cells of untreated diabetic animals compared to nondiabetic controls (Fig. 3A, Fig. 4). The expression was lower in all three intervention groups. In contrast, ET-1 protein expression in tubulointerstitial cells was not different between the groups (data not shown).

The effect of ACE-i and $\mathrm{ET}_{\mathrm{A}}-\mathrm{RB}$ on protein expression of fibronectin, a major component of the mesangial matrix (Fig. 3B). Fibronectin staining was higher in tubulointerstitial and vascular smooth muscle cells of untreated diabetic rats than in non-diabetic controls; it was less intensive in all treatment groups. In contrast, glomerular fibronectin expression was comparable in all groups.

PDGF (Fig. 3C): The effect of ACE-i and $\mathrm{ET}_{\mathrm{A}}-\mathrm{RB}$ on expression of PDGF protein, an important growth factor for mesangial cells (Fig. 3C). On the protein level PDGF-AB was expressed in mesangial, tubulointerstitial and vascular smooth muscle cells of untreated diabetic animals and the expression was more pronounced than in non-diabetic controls. It was less intense, however, in all treatment groups.

The effect of ACE-i and $\mathrm{ET}_{\mathrm{A}}-\mathrm{RB}$ on expression of TGF- $\beta 1$ protein is shown in figure $3 \mathrm{D}$. Glomerular and tubulointerstitial TGF- $\beta 1$ protein expression was higher in untreated diabetic rats than in controls. All treatment groups showed lower glomerular TGF- $\beta 1$ protein expression, but only ACE-i and combination treatment led to comparable glomerular and tubulointerstitial expression of TGF- $\beta 1$ as in controls. In contrast, treatment with $\mathrm{ET}_{\mathrm{A}}-\mathrm{RB}$ did not lower tubulointerstitial TGF- $\beta 1$ protein expression.

The effect of ACE-i and $\mathrm{ET}_{\mathrm{A}}-\mathrm{RB}$ on desmin positivity of podocytes (as an index of podocyte degeneration or damage) is shown in Fig. 5 and Fig. 6. Desmin positive podocytes were more frequent in untreated diabetic rats than in non-diabetic control rats, ACE-i and $\mathrm{ACE}-\mathrm{i}+\mathrm{ET}_{\mathrm{A}}-\mathrm{RB}$ treated rats. Treatment with $\mathrm{ET}_{\mathrm{A}}-\mathrm{RB}$ alone did not lower desmin positivity of podocytes.

Actin. By immunohistochemistry, mesangial cells or other glomerular cells were not positive for actin, a marker for mesangial cell activation, in any of the experimental groups (data not shown).

ET-1 mRNA by non radioactive in-situ hybridisation. Expression of ET-1 mRNA was higher in podocytes and mesangial cells of untreated diabetic rats than in non-diabetic controls (score: $1.49 \pm 0.18$ vs. $0.50 \pm 0.28$, Fig. 7A) or in treated diabetic rats, i.e. with ACE-i (score: $0.64 \pm 0.08$ ) or combination treatment (score: $0.55 \pm 0.43$ ). There was no difference between ET-1 mRNA expression in untreated diabetic animals and $\mathrm{ET}_{\mathrm{A}}-\mathrm{RB}$ treated diabetic rats (score: $1.18 \pm 0.01$ ). In the tubulointerstitium ET-1 mRNA expression was stronger in untreated diabetic animals than in non-diabetic controls and treated diabetic rats (Fig. 7B, Fig. 8). 


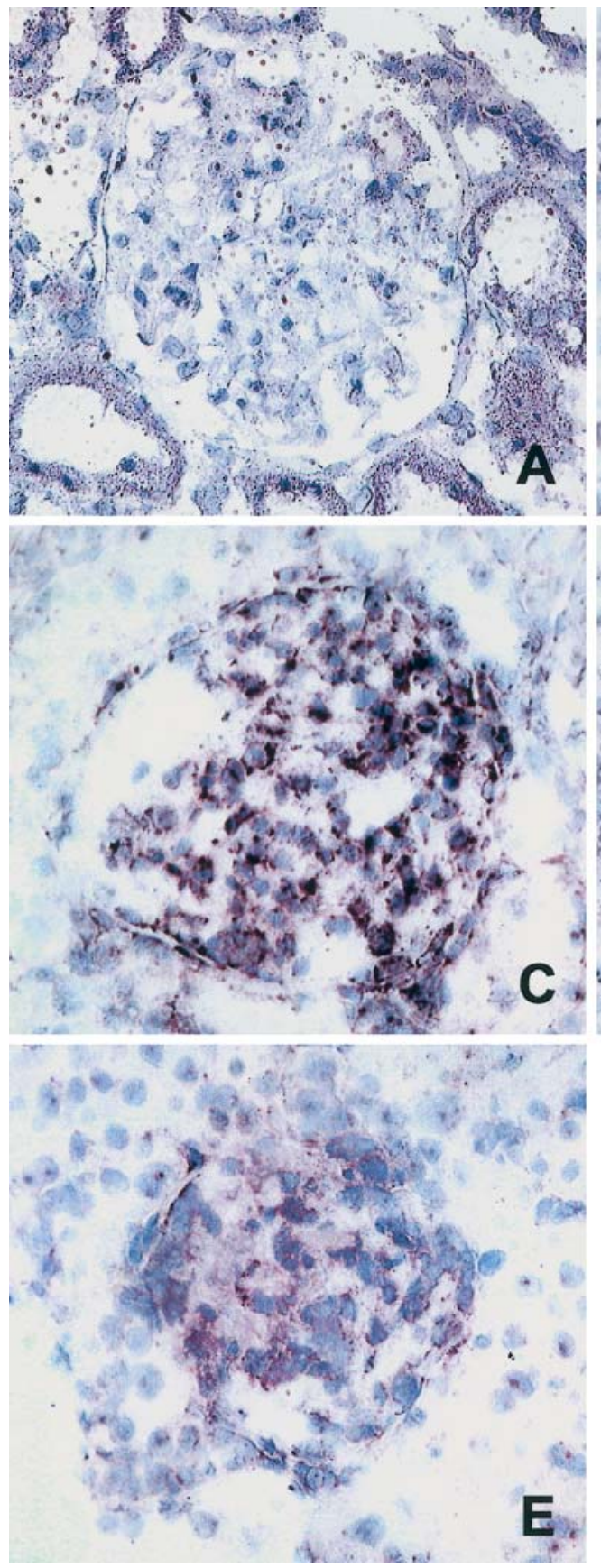

Fig. 8A-E. Effect of ACE-i and ET $_{\mathrm{A}}$-RB on glomerular ET-1 mRNA expression (non radioactive in-situ hybridisation, mag.: 1:300). (A) Non-diabetic control rat with virtually no ET-1 mRNA expression. (B) Untreated diabetic control rat with increased glomerular ET-1 mRNA expression. (C) $\mathrm{ET}_{\mathrm{A}}-\mathrm{RB}$ treated diabetic rat with less ET-1 mRNA expression of glomerular cells than in panel B. (D) ACE-i treated diabetic rat with only low glomerular ET-1 mRNA expression. (E) Diabetic rat treated with a combination of $\mathrm{ACE}-\mathrm{i}+\mathrm{ET}_{\mathrm{A}}-\mathrm{RB}$ and also only low glomerular ET-1 mRNA expression

\section{Discussion}

The importance of podocyte injury for progressive diabetic nephropathy has been documented in human

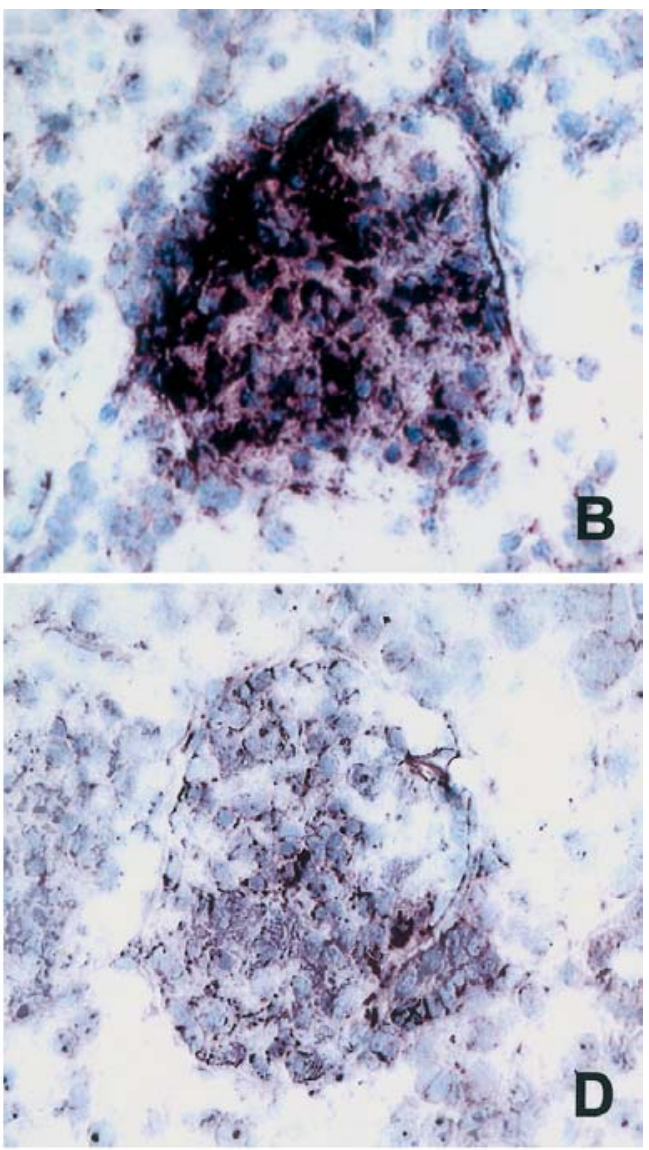

Type 2 diabetic patients: podocyte loss is seen in the early stages of progressive glomerulosclerosis in diabetic Pima Indians [29, 30]. Podocyte loss was also found in Type 1 diabetic patients [31]. In our study, STZ-induced diabetes led to marked activation of renal and specifically of podocyte ET- 1 expression and finally to a loss of podocytes. The loss of podocytes could be prevented by ACE-i and subsequently urinary albumin excretion was reduced. In contrast, treatment with $\mathrm{ET}_{\mathrm{A}}-\mathrm{RB}$ was ineffective in this respect. Podocyte damage and an abnormal podocyte phenotype was illustrated by increased staining for desmin as a sign for a switch-over to intermediate filament expression $[8,32,33]$. Treatment with ACE-i, but not with $\mathrm{ET}_{\mathrm{A}}-\mathrm{RB}$, led to lower glomerular staining for desmin.

Up-regulation of the CDK inhibitors p21 and p27Kip1 was shown in podocytes $[34,35]$ of diabetic rats. It has been suggested that $\mathrm{p} 27^{\mathrm{Kip} 1}$ stabilizes the cell cycle of these terminally differentiated cells [36]. Increased p27Kip1 expression is cell-protective and reflects a cellular reaction to injury or stress in podocytes [34]. This hypothesis is supported by our observation of increased $\mathrm{p} 27^{\mathrm{Kip} 1}$ expression in parallel with increased expression of PCNA by podocytes of untreated STZ diabetic rats. Interestingly, both ACE-i and $\mathrm{ET}_{\mathrm{A}}-\mathrm{RB}$ lowered $\mathrm{p} 2 \mathrm{~K}^{\mathrm{Kip} 1}$ and PCNA expression as well as glomerular hypertrophy, but only ACE-i pre- 
vented podocyte hypertrophy and staining for desmin. This observation suggests that ANG II influences pathways independent of p27 Kip1 and PCNA.

Based on studies in diabetic BB dp rats, it has been concluded that expression of $\mathrm{p} 27^{\mathrm{Kip} 1}$ is explained, at least in part, by higher TGF- $\beta$ levels [37]. TGF- $\beta$ expression was reduced by the ACE-i enalapril [37]. Our study documents that both $\mathrm{ACE}-\mathrm{i}$ and $\mathrm{ET}_{\mathrm{A}}-\mathrm{RB}$ reduced $\mathrm{p} 27^{\mathrm{Kip} 1}$ and TGF- $\beta$ expression, but only ACE- $\mathrm{i}$ preserves podocyte ultrastructure, providing further evidence that the Ang II and ET-1 operate through partially different pathways.

Progressive podocyte damage in diabetic fafa rats occurs through three potential pathways: (i) damage from hyperlipidaemia, (ii) damage from glomerular infiltration by monocyte/macrophages and (iii) damage resulting from glomerular hypertrophy [33]. In our study, serum cholesterol concentration was not increased in diabetic rats and we failed to find glomerular infiltration by monocyte/macrophages. In contrast, we could document glomerular hypertrophy. In a hypertrophied glomerulus an increased surface of basal membrane has to be covered by an unchanged number of podocytes. This mechanism is thought to cause podocyte injury. The explanation is definitely simplicistic, given the fact that in our study all interventions, both $A C E-i$ and $\mathrm{ET}_{\mathrm{A}}-\mathrm{RB}$, prevented glomerular hypertrophy, and yet only ACE-i prevented podocyte injury as reflected by staining for desmin. This finding, however, is in agreement with the observation by others [5] that reduction of the number of slit pores in podocyte foot processes of diabetic rats was prevented by ACE-i or AT1-receptor blockers. It is of interest that autoradiographic studies documented a high density of Ang II binding sites in glomeruli $[38,39]$. The presence of AT-1-subtype receptors for Ang II is illustrated by studies in podocyte cultures where Ang II depolarised podocytes [40]. Additionally, functional ET-1 receptors had been also found on podocytes [41].

This study in STZ-induced diabetic rats confirms that the earliest lesions are altered podocyte ultrastructure i.e. atypical expression of intermediate filaments of the desmin type. This is associated with increased expression of PCNA, presumably a reaction to cell injury rather than a marker of cell proliferation, because the number of podocytes decreases. Proliferation is presumably prevented by increased expression of p27Kip1. Although podocytes of diabetic animals show increased expression of ET-1, and although podocytes are known to have ET-receptors, blockade of the ET system by $\mathrm{ET}_{\mathrm{A}}-\mathrm{RB}$ failed to prevent the changes in ultrastructure and desmin expression. In contrast, Ang II seems to be causally involved, since ACE-i prevented the change in podocyte ultrastructure as well as expression of desmin PCNA and p27Kip1.
Acknowledgements. A. Koch and M.L. Groß are recipients of a grant in the Graduiertenkolleg "Nieren- und Kreislaufregulation" of the Deutsche Forschungsgemeinschaft. The study was supported by grants of the Deutsche Forschungsgemeinschaft (SFB 423, project B8) and the DAAD (323-PPP Hungary).

The skilful technical assistance of H. Ziebart, Z. Antoni, H. Derks, G. Gorsberg, D. Lutz, P. Rieger, S. Söllner, M. Weckbach and S. Wessels is gratefully acknowledged. The authors thank U. Reulbach, Dept. of Biostatistics, University of Erlangen-Nürnberg, for statistical advice and H. Derks and U. Burkhardt for the photographs and organizing the layout. The authors thank Dr. R. Truman, BASF Service II, Ludwigshafen, Germany, a native speaker, who corrected the manuscript.

\section{References}

1. Kohan DE (1992) Endothelins in the normal and diseased kidney. Am J Kidney Dis 29:2-26

2. Hargrove GM, Dufresne J, Whiteside C, Muruye DA, Wong NC (2000) Diabetes mellitus increases endothelin-1 gene transcription in rat kidney. Kidney Int 58:1534-1545

3. Hiromura K, Haseley LA, Zhang P et al. (2001) Podocyte expression of the CDK-inhibitor P57 during developmnet and disease. Kidney Int 60:2235-2246

4. Pagtalunan ME, Miller PL, Jumping-Eagle S et al. (1979) Podocyte loss and progressive glomerular injury in type 2 diabetes. J Clin Invest 99:342-348

5. Mifsud SA, Allen TJ, Bertram JF et al. (2001) Podocyte foot process broadening in experimental diabetic nephropathy: amelioration with renin-angiotensin blockade. Diabetologia 44:878-882

6. Pardee AB (1989) G1 events and regulation of cell proliferation. Science 246:603-608

7. Wolf G, Schroeder R, Zahner G, Stahl RAK, Shankland SJ (2001) High glucose-induced hypertrophy of mesangial cells requires p27Kip1, an inhibitor of cyclin-dependent kinases. Am J Pathol 158:1091-1100

8. Floege J, Hackmann B, Kliem V et al. (1997) Age-related glomerulosclerosis and interstitial fibrosis in Milan normotensive rats: a podocyte disease. Kidney Int 51:220-243

9. Cooper ME (2001) Interaction of metabolic and haemodynamic factors in mediating experimental diabetic nephropathy. Diabetologia 44:1957-1972

10. Schwarz U, Amann K, Orth S, Simonaviciene A, Wessels S, Ritz E (1998) Effect of 1,25 $(\mathrm{OH})_{2}$ vitamin D3 on glomerulosclerosis in subtotally nephrectomized rats. Kidney Int 53:1696-1705

11. Dhein S, Hochreuther S, Spring C aus dem et al. (2000) Long-term effects of the endothelin A receptor antagonist LU135252 and the angiotensin-converting enzyme inhibitor Trandolapril on diabetic angiopathy and nephropathy in a chronic type 1 diabetes mellitus rat model. J Pharmacol Exp Ther 293:351-359

12. Gilbert RE, Cox A, Wu LL et al. (1998) Expression of transforming growth factor $\beta 1$ and type IV collagen in the renal tubulointerstitium in experimental diabetes. Diabetes 47:414-422

13. Mauer SM, Steffes MW, Brown DM (1979) Animal models of diabetic nephropathy. In: Hamburg J, Gesmir J, Pfrenfeld J, Maxwell MH (eds) Advances in nephrology, vol 8, Year Book Medical Publishers, Chicago London

14. Philipps AO, Baboolal K, Riley S, Groene HJ et al. (2001) Association of prolonged hyperglycemia with glomerular hypertrophy and renal basement membrane thickening in the Goto Kakizaki model of non-insulin-dependent diabetes mellitus. Am J Kidney Dis 37:400-410 
15. Amann K, Kronenberg G, Gehlen F et al. (1998) Cardiac remodelling in experimental renal failure - an immunohistochemical study. Nephrol Dial Transplant 13:1958-1966

16. Wolf SC, Brehm BR, Gaschler F et al. (1999) Protective effects of endothelin antagonists in chronic renal failure. Nephrol Dial Transplant 4 [14 Suppl]: 29-30

17. El Nahas AM, Bassett AH, Cope GH, Carpentier JE (1991) Role of growth hormone in the development of experimental renal scarring. Kidney Int 40:29-34

18. Ghandi M, Olson JL, Meyer TW (1998) Contribution of tubular injury to loss of remnant kidney function. Kidney Int 54:1157-1165

19. Veniant M, Heudes D, Clozel JP, Bruneval P, Menard J (1994) Calcium blockade versus ACE inhibition in clipped and unclipped kidneys of $2 \mathrm{~K}-1 \mathrm{C}$ rats. Kidney Int 46:421429

20. Weibel ER (1997) Stereological methods. In: Practical methods for biological morphometry. Academic Press, London, pp 100-167

21. Weibel ER (1997) Stereological methods. In: Theoretical foundation, vol 2. Academic Press, London, pp 56-139

22. Amann K, Koch A, Hofstetter J et al. (2001) Glomerulosclerosis and progression: effect of subantihypertensive doses of $\alpha$ and $\beta$ blockers. Kidney Int 60:1309-1323

23. Amann K, Nichols C, Toernig J et al. (1996) Effect of ramipril, nifedipine, and moxonidine on glomerular morphology and podocyte structure in experimental renal failure. Nephrol Dial Transplant 11:1003-1011

24. Guo G, Morrisey J, McCracken R, Tolley T, Liapis H, Klahr S (2001) Contribution of angiotensin II and tumor necrosis factor-alpha to the development of renal fibrosis. Am J Renal Physiol 280: F777-785

25. Amann K, Münter K, Wessels S et al. (2000) Endothelin A receptor blockade prevents capillary/myocyte mismatch in the heart of uremic animals. J Am Soc Nephrol 11:16911699

26. Amann K, Rump LC, Simonaviciene A et al. (2000) Effects of low dose sympathetic inhibition on glomerulosclerosis and albuminuria in subtotally nephrectomized rats. J Am Soc Nephrol 11:1469-1478

27. Nabokov A, Amann K, Wessels S, Muenter K, Wagner J, Ritz E (1999) Endothelin receptor antagonists influence cardiovascular morphology in uremic rats. Kidney Int 55:512-519

28. Goettsch W, Lattmann T, Amann K et al. (2001) Increased expression of endothelin-1 and nitric oxide synthase iso- form II in aging arteries. Implications for atherogenesis. Biochem Biophys Res Comm 280:908-913

29. Lemley KV, Blouch K, Abdullah I et al. (2000) Glomerular permselectivity at the onset of nephropathy in type 2 diabetes mellitus. J Am Soc Nephrol 11:2095-2105

30. Meyer TW, Bennett PH, Nelson RG (1999) Podocyte number predicts long-term urinary albumin excretion in Pima Indians with type 2 diabetes and microalbuminuria. Diabetologia 42:1341-1344

31. Steffes MW, Schmidt D, McCrery R, Basgen JM, the International Study Group (2001) Glomerular cell number in normal subjects and in type 1 diabetic patients. Kidney Int 59:2104-2113

32. Floege J, Bums MW, Alpers CE et al. (1992) Glomerular cell proliferation and PDGF expression proceed glomerulosclerosis in the remnant kidney model. Kidney Int 41:297309

33. Coimbra TM, Janssen U, Gröne HJ et al. (2000) Early events leading to renal injury in obese Zucker (fatty) rats with type 2 diabetes. Kidney Int 57:167-182

34. Hoshi S, ShuY, Yoshida F et al. (2002) Podocyte injury promotes progressive nephropathy in Zucker diabetic fatty rats. Lab Invest 82:25-35

35. Wolf G, Schroeder R, Thaiss F, Ziyadeh FN, Helmchen U, Stahl RAK (1998) Glomerular expression of p27Kip1 in diabetic $d b / d b$ mouse: Role of hyperglycemia. Kidney Int 53:869-879

36. Nagata M, Yamaguchi Y, KomatsuY, Ito K (1995) Mitosis and the presence of binucleate cells among glomerular podocytes in diseased human kidneys. Nephron 70:68-71

37. Wolf G, Wenzel U, Zidayeh FN, Stahl RAK (1999) Angiotenin converting-enzyme inhibitor treatment reduces glomerular p16 INK4 and p27KIP1 expression in diabetic $B B d p$ rats. Diabetologia 42:1425-1432

38. Yamada H, Sexton PM, Chai SY, Adam WR, Mendelsohn FA (1990) Angiotensin II receptors in the kidney. Localisation and physiological significance. Am J Hypertens 3:250-255

39. Kriz W, Hackenthal E, Nobiling N, Sakai T, Elger M (1994) A role for podocytes to counteract capillary wall distension. Kidney Int 45:369-376

40. Gloy J, Henger A, Fischer KG et al. (1997) Angiotensin II depolarizes podocytes in the intact glomerulus of the rat. $\mathrm{J}$ Clin Invest 99:2772-2781

41. Rebibou JM, He CJ, Delarue F et al. (1992) Functional endothelin 1 receptors on human glomerular podocytes and mesangial cells. Nephrol Dial Transplant 7:288-292 